\title{
SEPARATION OF XYLENE ISOMERS THROUGH ADSORPTION ON MICROPOROUS MATERIALS: A REVIEW
}

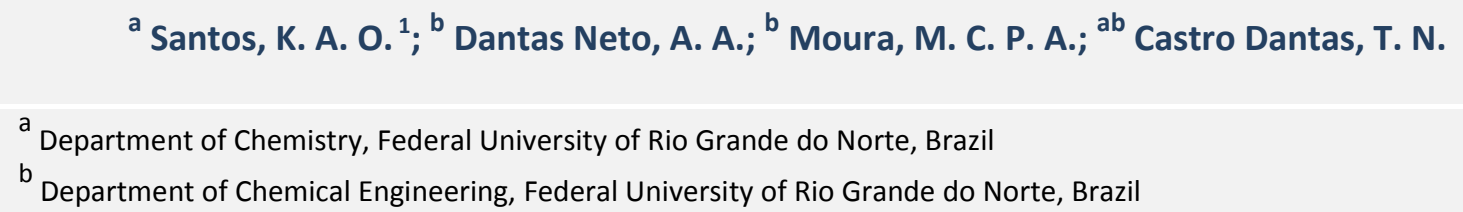

\section{ABSTRACT}

Xylene is an aromatic hydrocarbon with a single ring and two methyl groups attached to this ring in positions 1-2, 1-3 and 1-4, called $o$-xylene, $m$-xylene, and $p$-xylene, respectively. Because of the similarities in their physicochemical properties, it is very difficult to obtain these isomers in a pure form. For this reason, numerous techniques have been developed with the objective of separating them. One technique is based on the adsorption of substances according to the adsorption heat observed during their interaction with the adsorbent. This review presents the main studies developed in recent years that seek to evaluate the potential of microporous materials in separating the different xylene isomers.

\section{KEYWORDS}

xylene isomers; separation; adsorption; microporous materials; zeolite

\footnotetext{
${ }^{1}$ To whom all correspondence should be addressed.

Address: Federal University of Rio Grande do Norte, Department of Chemistry, Campus Universitário | Postal Code 59078-970, Natal, RN, Brazil

Telephone / Fax: +55 8432153773 / +55 843215 3156| E-mail: santos kao@yahoo.com.br doi:10.5419/bjpg2011-0024
} 


\section{INTRODUCTION}

Xylene isomers are aromatic compounds obtained from petroleum. The chemical structure of these isomers is formed by one benzene ring and two methyl groups bonded to the ring in three different positions. The name xylene is commonly used to designate the commercial mixture of the three isomers, namely ortho-xylene, meta-xylene, and para-xylene; or 1,2-dimethylbenzene, 1,3dimethylbenzene, and 1,4-dimethylbenzene, respectively (Health Canada, 1986). Because these substances are isomers and have similar physicochemical properties, the process of producing pure isomers is intricate. Its relevant industrial applications, especially in the plastic industry, have lead to the development of a variety of studies that focus on the use of new materials. These studies have the objective of optimizing existing processes that seek to obtain pure isomers, with an emphasis on the improvement of the separation efficiency of xylene isomers.

Xylene isomers are obtained by the catalytic process of naphtha reforming originated from the primary distillation of petroleum. During this process, the isomers are separated from other hydrocarbons by a catalytic wheel containing platinum-halogen. The production of pure xylene by the petrochemical industry starts with the separation of a fraction comprising hydrocarbons with eight carbon atoms, the $\mathrm{C}_{8}$ fraction, which feeds the xylene column. Then, the effluent from this xylene column will feed a PAREX unit to obtain the $p$-xylene (extract). The refined product is pumped through an ISOMAR unit, where the isomers are converted to $p$-xylene. After this stage, the unused materials return to the xylene column (Meyers, 2003).

Among the three isomers of xylene, $p$-xylene has the highest melting temperature at $\mathrm{T}_{\mathrm{m}}=13.3^{\circ} \mathrm{C}$ and, for this reason, can be separated by fractional crystallization, with a recovery rate of only $50 \%$ of the $p$-xylene present in the mixture. This process is affected negatively by the formation of a eutectic mixture of xylene components. The low yields of the $p$-xylene production process render the industrial process unfeasible. The $o$-xylene reaches its highest boiling temperature at $144.4{ }^{\circ} \mathrm{C}$, and achieves its $95 \%$ purity rate through fractional distillation, containing impurities of the $C_{9}$ type. The vast majority of available research that focuses in investigating the optimal separation of isomers is limited to the study of the binary mixtures $p$ xylene $/ m$-xylene and $m$-xylene/o-xylene (Santacesaria, 1980).

The importance of obtaining pure isomers resides in the industrial production of PET (polyethylene terephthalate), which is a thermoplastic polymer formed by the reaction between terephthalic acid and ethylene glycol, largely used in the production of plastic bottles. $p$ Xylene is the raw material necessary to the production of terephthalic acid. $o$-Xylene is used in the production of phthalic anhydride and $m$-Xylene is used in the production of isophthalic acid. All these substances are used in the plastic and rubber industries, as well as in gasoline additives. The use of products with high levels of purity enhance process efficiency and decrease the costs associated with industrial production (Antos and Flint, 1985; Health Canada, 1986; Santacesaria, 1980).

The PAREX process, developed by Universal Oil Products (UOP) for the production of $p$-xylene in 1969 was pioneer in applying the principle of adsorption separation in industrial scale. By this process, a liquid mixture was separated using a molecular sieve. A complex equipment system was used, and the separation was effected by moving the adsorbent's counter-current periodically toward the flow of the liquid, whilst the original mixture remained in a sequence of stationary beds (Morbidelli et al., 1986; Santacesaria, 1980).

The process of separation based on selective adsorption was possible, initially, by comparing the kinetic diameter of the substances to be separated and the diameter of the absorbent pore used in the separation. This technique brought to light the term molecular sieve, considering that the adsorbents promote the separation at a molecular level as if they were sieves. The adsorbent's pore characteristic is not the only factor influencing the separation process in this method, but it serves as the starting point. Selective adsorption is the first technique to be considered in the separation process. However, characteristics such as the individual component adsorption heat (Santacesaria, 1980), the transfer load on adsorbent's surface, the affinity between sorbent and solute, and the parameters of diffusion (Tarditi and Lombardo, 2008) also need to be considered. 
Table 1. Characteristics of xylene isomers.

\begin{tabular}{cccc}
\hline Xylene isomer & $\begin{array}{c}\text { Boiling point } \\
\mathrm{T}_{\mathrm{e}} /{ }^{\circ} \mathrm{C}\end{array}$ & $\begin{array}{c}\text { Melting point } \\
\mathrm{T}_{\mathrm{f}} /{ }^{\circ} \mathrm{C}\end{array}$ & $\begin{array}{c}\text { Kinetic diameter } \\
k_{\mathrm{c}} / \mathrm{nm}\end{array}$ \\
\hline para-xylene & 138.3 & 13.4 & 0.58 \\
meta-xylene & 139.1 & -47.9 & 0.68 \\
ortho-xylene & 144.4 & -25.2 & 0.68 \\
\hline
\end{tabular}

Table 1 shows the characteristics of some xylene isomers considered to be important by researchers when investigating the methodologies of separation through the use of selective adsorption (Santacesaria, 1980; Tarditi and Lombardo, 2008; Wegner et al., 1999; Xomeritakis and Tsapatsis, 1999).

Technical-scientific literature reports numerous patents and periodical articles on the use of several principles to separate xylene isomers (Adams, 1971; Amir, 1970; Antos and Flint, 1985; Baddour and Michaels, 1967; Berg, 1991; Berg, 1992; Bown, 1957; Bown and Milligan, 1957; Eberly and Arey, 1964; Faulkner, 1975; Fleck and Wight, 1961; Greene, 1950; Hoff and Burney, 1958; Lake and Mcdowell, 1948; McCaulay, 1967; Mikitenko and Macpherson, 2000; Nixon and Deal, 1953; Nixon et al., 1950; Pearce, 1976; Schaeffer, 1966; Schaeffer and Wordie, 1960; Shaeffer and Wordle, 1957; Smolin, 1967; Smolin, 1982; Stenmark, 1972; Swalowski and Rai, 1968; Talbot, 1956; Tan, 1993; Walker and Long, 1971; Zinnen and Mcgonegal, 2000). Considering the existence of a large volume of work published on this subject, it is difficult to consolidate all of them in the same review. Nevertheless, recognizing the existence of a variety of processes for obtaining pure xylene, this work will focus on the ones that use adsorption principles to promote the separation of these isomers. This choice reflects the importance of pure isomers in industrial applications.

This study aims to analyze the separation phenomena and the difficulties that occur during the separation of xylene isomers. Initially, this study will provide a brief overview of zeolites and their use in the separation of xylene isomers. Following, there will be a discussion on the methodologies used to evaluate the potential of zeolites in the separation processes. This review will compare the studies that used microporous materials, such as zeolites, to improve separation experiments. At last, all results will be critically compared to propose practical contributions to the field.

\section{ZEOLITES: DEFINITION, PROPERTIES AND CHARACTERIZATION}

Zeolites are inorganic hydrated compounds formed by atoms of aluminum, silicon, oxygen and metals that are usually present in the first or second column of the periodic table. The zeolite's structure is composed by interconnected ducts of molecular size, which create a large internal surface when compared to its external surface, presenting unique properties that can explain its broad applications (Breck, 1974). Zeolites can be divided into two categories: natural zeolites such as laumontite, clinoptilolite, offretite, and mordenite, among others; and synthetic zeolites of types $A, X$ and $Y$ (Flanigen, 1980). The most frequent form of zeolite has the general composition formula $\mathrm{TO}_{4}$, where $T$ represents the silicate or the aluminum atom connected to oxygen atoms. Its chemical formula per unit cell composition is:

$\mathrm{M}_{\mathrm{x} / \mathrm{n}} \cdot\left[\left(\mathrm{AlO}_{2}\right)_{\mathrm{x}}\left(\mathrm{SiO}_{2}\right)_{\mathrm{y}}\right] \cdot \mathrm{w} \mathrm{H} \mathrm{H}_{2} \mathrm{O}$

where $M$ is the cation, $w$ is the number of water molecules and $(x+y)$ is the number of tetrahedra per unit cell.

Zeolites are known as molecular sieves due to their numerous pores with different sizes and their use in the separation of molecular compounds at a molecular level. According to the rules of the International Union of Pure and Applied Chemistry (IUPAC), zeolites are classified as microporous materials which have pores with diameters smaller than $2 \mathrm{~nm}$ (Rouquerol et al., 1994). The zeolite pores present a crystal structure with excellent chemical resistance, homogeneous dimensions and uniform distribution. According to Sayari (1996), the microporous materials pore sizes and their different structures are used to indicate the application of an adsorbent. For example, the ZSM5 zeolite has the potential to separate xylene 
isomers based on its average pore size between 0.6 and $0.7 \mathrm{~nm}$.

The most relevant properties of zeolites are its cation exchange capacity, high degree of hydration, low density, the presence of a large volume of empty spaces within its rigid structure, stable structure when dehydrated, uniform channel sizes within its crystal structure, electrical conductivity, ability to adsorb gases and vapors, and compatibility for catalytic cracking processes. The cation exchange capacity increases zeolite efficiency in a given application. Depending on the exchanged cation, the internal ducts will shrink or expand its dimensions. Following the cation exchange, other significant changes take place. For example, Tarditi and Lombardo (2008) investigated the influence of cation exchange in ZSM-5 zeolites, MFI-type, supported by stainless steel, by means of secondary growth technique that allows the crystals grow directly upon a surface over a layer of crystals that have originated from a primary growth serving basis (or Foundation). They used $\mathrm{Na}^{+}, \mathrm{Cs}^{+}$, $\mathrm{Ba}^{2+}$, and $\mathrm{Sr}^{2+}$, and noticed that the flux of the substances under investigation through the zeolite did not shrink in the same level as the increase of size of the cation. They concluded that there are other factors that influence the flow of substances through the channels, such as the interaction with the adsorbent and the solute. This application allows the use of zeolites in agriculture, in the formulation of detergents, and in the treatment of aqueous effluents.

The low density is directly correlated with the presence of large empty areas, or caves, since zeolitic materials with large volume of pores have a greater chance to present low density. Its thermal stability favors the synthesis of these materials, especially during the removal of the template. Even

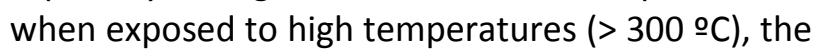
zeolite is able to maintain its physical structure. The removal of gases and vapors, along with its catalytic properties, allow the use of zeolites in the purification and industrial separation of gases, odor control, and in catalytic reactions. In these cases, the processes occur within the materials, and the internal surface acts as a catalyst, normally lowering the activation energy in the formation of new substances.

The synthesis of zeolites has been widely reported. The zeolite characterization determines the pore volume and the pore size, among other important characteristics that can be used in a particular application. Presently, the world's largest research centers are using similar characterization techniques. X-ray diffraction (XRD) is the technique used to evaluate zeolite microstructures (Matsufuji et al., 2000; O'brien-Abraham et al., 2008; Sakai et al., 2001; Tarditi et al., 2006; Xomeritakis and Tsapatsis, 1999). Scanning electron microscopy (SEM) is the technique used to determine the morphology of the material (Deng et al., 2010; Moreira et al., 2011a). This apparatus may come attached to an electron-probe micro-analyzer (EPMA), used to analyze the composition of the zeolite more precisely (O'brien-Abraham et al., 2008; Tarditi et al., 2008; Wegner et al., 1999). Infrared spectroscopy (IR) and nuclear magnetic resonance (NMR) can also assist in this investigation (Guo et al., 2000).

Among the various applications of zeolites, one can highlight its use as a catalyst and as a molecular sieve, selecting substances according to its pore sizes. In the petrochemical industry, $p$ xylene is produced with the use of zeolites. This review will present a summary of the main studies that sought to optimize the separation of xylene isomers, using surface adsorption principles, focusing the investigations on the application of new zeolitic materials.

\section{SEPARATION OF XYLENE ISOMERS}

Among the greatest challenges to industrial processes that seek to separate substances and produce raw materials to other units, the fracturing of xylenes and ethylbenzenes into pure isomers is very important. Particularly, there is much interest in obtaining the $p$-xylene isomer due to its industrial relevance if compared to the other substances that form the mixture. Papers devoted to this subject have been compiled in the literature since the 1940's (Lake and Mcdowell, 1948). Santacesaria (1980) reviewed the existing methods of separation used with xylene isomers, and the principles on which these methods were based. Among them, the author cited the ones that used adsorption to promote the separation of isomers, highlighting the use of zeolites. Santacesaria has also elected Eberly and Arey as pioneers in the application of adsorption techniques in the 
separation of xylene isomers, reporting the experiment where they used molecular sieves with 10-13 A pore diameter with a mixture in boiling phase (Eberly and Arey, 1964). In 1981, Rosback performed studies that involved the separation of aromatic isomers. His experiment used faujasites $X$ and $Y$, and modified the isomers' active site by employing different amounts of barium oxide and potassium. The faujasite $X$ was modified with barium oxide $(22.1 \%, 25.1 \%$, and $31.5 \%)$ and potassium oxide $(6.1 \%, 3.1 \%$, and $0.0 \%)$. During the experiment four different adsorbents were synthesized. The separation assays were performed in aqueous phase, using toluene and $p$ dimethylbenzene as solvents. The focus of the investigation was to determine the selectivities of the mixture's components. The experiment determined the selectivities between $p$-xylene and ethylbenzene; $p$-xylene and $m$-xylene; $p$-xylene and $o$-xylene; and $p$-xylene and $p$-diethylbenzene. Both treated and non-treated adsorbents were used in these assays. The treatment was performed using dimethylamonium chloride and methylamonium hydrochloride. The results showed that the majority of the adsorbents had their selectivities increased after the treatment. The selectivity obtained to $p$-xylene comparing to the $p$ diethylbenzene served to assess the potential of this last as a dissolver. After synthesis and treatment of the faujasite $X$ modified with barium oxide (22.1\%) and potassium oxide (6.1\%), an adsorbent with good performance was produced when using $p$-diethylbenzene as dissolver, considering that the values for selectivity were greater than 2.0 (Rosback, 1981). Antos and Flint (1985) used X-type zeolites containing silver cations at their active sites to separate $o$-xylene from its isomers. Their experiment used a flow system simulating a counter-current stationary bed. During the recovery of the adsorbed substance, $p$-dimethylbenzene was used as solvent. The adsorption process was performed with the temperature ranging from 20 to $250{ }^{\circ} \mathrm{C}$, and with enough pressure to maintain the liquid phase. The $o$-xylene's selectivities were: 1.81 in comparison with $p$-xylene, 1.71 in comparison with ethylbenzene, and 1.64 in comparison with $\mathrm{m}$ xylene. According to the selectivity results, the methodology used was considered efficient in the separation of $o$-xylene from its isomers. Nevertheless, some researchers consider selectivities with values under 2 to be commercially unsuitable (Antos and Flint, 1985).
Unlike previous research, that used zeolites types $X$ and $Y$ for xylene separation, a number of scientists focused their studies in investigating MFItype zeolites, particularly the ZSM-5 type (Baertsch et al., 1996; Brzostowska et al., 1981; Guo et al., 2000; Namba et al., 1984; Yan, 1989). The ZSM-5 is a microporous material belonging to the MFI family, composed by silicon and aluminum atoms. Its crystals are organized in a straight line and its sinusoidal channel of $0.55-\mathrm{nm}$ diameter crosses the structure perpendicularly. Guo et al. (2000) performed the separation of $p$-xylene from the mixture of aromatic compounds with eight carbon atoms using a hydrophobic, MFI-type zeolite, carrying out a study under static equilibrium. As the expression suggests, the problem mixture is placed in contact with the adsorbent during 1 to 2 hours at a temperature of approximately $25^{\circ} \mathrm{C}$. The analyses were performed by gas chromatography using mesitylene (1,3,5-trimethylbenzene) as internal standard. The choice to set this substance as the internal standard was due to its inertia against the problem mixture and the fact that it had a kinetic diameter of $0.75 \mathrm{~nm}$, much greater than the zeolite pore diameter. The membrane used was the very hydrophobic H-MFl-type, containing high levels of silica. Based on the test performed, it was possible to conclude that the separation membrane was selective for $p$-xylene (Guo et al., 2000).

In the same year, Zinnen and McGonegal (2000) used beta zeolites to separate $m$-xylene from the other isomers. Unlike the methodologies previously examined, $m$-xylene was separated due its inability to be adsorbed by the zeolite. After recovery of $m$ xylene, the adsorbent was separated using toluene, benzene, or a mixture of the two as solvent (Zinnen and McaGonegal, 2000).

Following this line of research, several papers have been published on this topic with the same objective but reporting experiments that slightly differ from the former ones. Nowadays, the scientific literature archives offer over 1,400 research papers with the keyworks "adsorption" and "xylene". Table 2 lists examples of scientific papers that use adsorption in microporous materials in the separation of xylene isomers.

The scientific papers listed in Table 2 report mainly on isomer mixtures in vapor phase. The studies developed within the last twenty years 
Table 2. Microporous materials used in thes separation of xylene isomers.

\begin{tabular}{ll}
\hline Microporous materials & \multicolumn{1}{c}{ References } \\
\hline & $\begin{array}{l}\text { (Baertsch et al., 1996; Brzostowska et al., 1981; Daramola et } \\
\text { al., 2010; Deng et al., 2010; Guo et al., 2000; Matsufuji et al., } \\
\text { 2000; Namba et al., 1984; O'brien-Abraham et al., 2011; } \\
\text { O'brien-Abraham et al., 2008; Rasouli et al., 2011; Sakai et al., } \\
\text { 2001; Tarditi and Lombardo, 2008; Xomeritakis et al., 2001; } \\
\text { Yan, 1989). }\end{array}$ \\
& $\begin{array}{l}\text { (Alaerts et al., 2008; Denayer et al., 2008; Finsy et al., 2009; } \\
\text { MIL-53 (ZSM-5 and others) al., 2008; Moreira et al., 2011a; Moreira et al., 2011b). }\end{array}$ \\
MIL-47 & (Castillo et al., 2009; Finsy et al., 2008). \\
X-type & (Furlan et al., 1992; Jin et al., 2009; Zhao et al., 2005). \\
& (Carrà et al., 1982; Methivier, 1998; Milewski and Berak, 1975; \\
Morbidelli et al., 1985; Santacesaria et al., 1985; Santacesaria \\
et al., 1982a; Santacesaria et al., 1982b; Storti et al., 1992; \\
Storti et al., 1985).
\end{tabular}

used crystalline zeolite powder and composite zeolite membranes. Researches involving metalorganic frameworks (MOFs) have been published in more recent years. The use of membranes in the separation of xylene isomers started in the beginning of the 1990's, and, according to Jansen and Coker (1996), zeolite membranes are formed by a layer of zeolite that is prepared on the surface of a porous support. The most challenging issues involving the synthesis of zeolite membranes is to prevent malformations and achieve optimal permeability (Jansen and Coker, 1996). Baertsch et al. (1996), for example, used silicate-zeolite membranes in experiments of permeation of polymers with the purpose of verifying the application of this type of zeolite in the separation of mixtures that contained benzene, toluene, ethylbenzene, and xylene isomers. The experiments were carried out observing the behavior of pure and mixed flows, through a comparative analysis of the results. Magnitudes such as a boiling point, kinetic diameter, diffusivity, permeation index, and activation energy were observed during data analysis. The experiment investigated four binary and one ternary mixture, namely: $p$-xylene and $o$-xylene; $p$-xylene and ethylbenzene; $p$-xylene and toluene; $m$-xylene and ethylbenzene; benzene, toluene and $p$-xylene. Based on the results obtained, no separation occurred. The study concluded that the permeation non-accompanies the ascending kinetic diameter size of the studied substance and other parameters must be investigated. Apparently, the whole molecule has the same probability of entering the pores, but its entrance does not affect permeation indexes.

In 1999, Wegner and coworkers performed a synthesis of a separation membrane formed by $\alpha$ alumina supported on a MFI-type zeolite, by means of an in situ hydrothermal synthesis. The experiment used tetrapropylammonium hydroxide (TPAOH) in solution to obtain $1.5-\mu \mathrm{m}$ zeolites. Differently from experiments that used mixtures already in the vapor phase, an originally liquid mixture was vaporized in a process called pervaporation. These tests allowed the researchers to observe that the pervaporation flow decreased with time, a behavior that was attributed to the formation of $\pi$ complexes between the benzene ring and the zeolite cations. The aromatic compounds are substances that donate electrons and the materials with cationic sites are electrophilic. Considering that the zeolite used in the experiment was of the MFI-type (ZSM-5) and not silicalite, the exchange phenomenon described above can occur. After formation of the complexes, there is a complete blockage of the zeolite pores, 
and the non-zeolite pores are only partially blocked. Therefore, one could not observe the separation of the investigated mixtures ( $p$-xylene and $o$-xylene; and $p$-xylene and $m$-xylene).

In order to improve the quality of the membrane and the reproducibility of the results published elsewhere, Xomeritakis and Tsapatsis (1999) developed their line of thought based on the permeation of vapors of aromatic isomers through membranes synthesized by the secondary growth method. This method, unlike the in situ technique, does not comprise a nucleation stage and has the objective of minimizing the interzeolite porosity. The secondary method involves the deposition of the primary layer of seed zeolite crystals of nanometric size on the support, thereby inducing the growth of a new secondary layer of the same crystals and forming a continuous film, which ultimately forms the membrane. The advantages of this method are the flexibility, the control of the films' microstructure, the reproducibility, and the scalability. The zeolite membrane synthesized was the MFI-type silicate and the separated mixture was formed exclusively by xylene isomers. The results of the experiments were positive, considering that the researchers were able to determine the important aspects in order to perform the separation, such as the MFItype silicate membrane, obtained from the secondary growth, which cannot work under high temperatures $\left(>100{ }^{\circ} \mathrm{C}\right)$ at the risk of diminishing its separation efficiency. Also, the experiment concluded that ortho and meta isomers permeate at a slower pace than the para isomers, and that $p$ xylene permeation causes structural changes on the membrane. Once the permeation rates are established, the membranes in question have the potential of separating xylene isomers in mixtures, especially $p$-xylene (Xomeritakis and Tsapatsis, 1999).

Nair et al. (2001) investigated the mechanism of permeation of xylene isomers in membranes of MFI-type silicalite zeolite. The scientists also used FAU-type zeolite membranes. Both membranes were prepared through secondary growth and used polished $\alpha$-alumina as support. Using the MFI-type zeolite, the membranes were prepared with the same reaction mixture (4 $\mathrm{SiO}_{2}: 0.9 \mathrm{TPABr}$ (tetrapropylammonium bromide) : $950 \mathrm{H}_{2} \mathrm{O}: 16$ EtOH), but were synthesized at different temperatures, times of crystal formation, and calcination times. Following the synthesis, the membranes were characterized by traditional methods (X-ray diffraction and SEM) and by confocal microscopy (Bonilla et al., 2001). This work obtained three types of membrane. The first membrane was the MFI-type silicalite with $15-\mu \mathrm{m}$ thickness and c-out-of-plane orientation of columnar microstructure with (1 011 ) facets visible at an angle to the surface. The second was also a MFI-type silicalite with (1-3)- $\mu \mathrm{m}$ thickness and (1 0 1) oriented, possessing a smooth surface. The latter, after calcination, was sealed with a solution of silica and surfactant. The former membrane was considered in the evaluation of its separation potential. In order to evaluate the MFI membranes' potential, this group of scientists created isotherms that correlated the permeation flow with partial feed pressures. With the results for the first membrane, analyzing each isomer separately, and, later, using a binary mixture of $p$-xylene and $o$ xylene, the scientists verified that the $p$-xylene flow did not saturate, but increased with the increase in the partial feed pressure. An opposite behavior was observed for $o$-xylene, since it saturated under partial pressures with moderate values, and then immediately increased with the increase in pressure. However, the o-xylene flow values displayed an order of magnitude almost twice smaller than the $p$-xylene flow. For this reason, when separated, these isomers present high selectivity, since $p$-xylene permeates through the membrane much faster than $o$-xylene (selectivity 100 , at $\left.50{ }^{\circ} \mathrm{C}, \mathrm{P} / \mathrm{P}_{\text {sat }} \cong 0.6\right)$. The easy permeation of $p$-xylene though the membrane suggests that the grain boundaries contribute significantly to its transport action through this intergrain porosity, and its adsorption may have its origins on the progressive opening of these spaces. Other phenomena taken into account included capillary condensation within the zeolite pores and adsorption and diffusivity between the two isomers. However, when the binary mixture was permeated, the results were not satisfactory and the membrane did not present good selectivity. This phenomenon is explained by the fact that $p$ xylene opens a path to the other isomer which, on its own, did not develop sufficient adsorptive diffusion rates to achieve such task. Moreover, the order of magnitude of the flow was the same for both isomers. When the experiments were performed with the sealed membrane, high selectivity (20 to 300 ) was obtained for $p$-xylene. These results demonstrate the influence of defects 
in the membrane selectivity. It was observed, then, that these imperfect membranes were formed after the calcination stage. A large number of researchers advocated that these defects are a result of thermal incompatibility between the support and the zeolite membrane (Nair et al., 2001).

In an attempt to solve the problems related to membrane imperfections, Sakai et al. (2001) developed a self-supported MFI-type zeolite membrane that offered good thermal resistance. They tested the membrane efficiency in the separation of xylene mixtures by means of permeation experiments. In the tests, the flow behavior was investigated as a function of temperature, time, partial pressure, and membrane thickness. When evaluating the dependence of the flow with time, at $473 \mathrm{~K}, 573 \mathrm{~K}$ and $673 \mathrm{~K}$, they found that the flow was constant. However, at $373 \mathrm{~K}$, the $p$-xylene flow decreased within the first hours, whilst the flow of the other two isomers increased slightly and slowly. At $303 \mathrm{~K}$, the flow behavior was completely different; $p$ xylene presented its lowest flow rate within the first hours, and practically the same rate was observed for the other isomers 24 hours later. Concerning the relationship between flow and temperature, studies prove that the optimal temperature for separation is $473 \mathrm{~K}\left[8.2 \times 10^{-8}\right.$ $\left.\mathrm{mol} /\left(\mathrm{m}^{2} . \mathrm{s} . \mathrm{Pa}\right)\right]$. In the phenomenon, the amount adsorbed is based on the equilibrium, decreasing with increasing temperature. Moreover, since the diffusion is an activated process, the diffusiveness increases as the temperature increases. Therefore, optimal flow will occur when the equilibrium between adsorption and diffusion is achieved. The results also prove that the best partial pressure obtained in the experiment was $0.3 \mathrm{kPa}$, due to the competitive effects previously cited and the selectiveness of the membrane for $p$-xylene. The separation factor observed for $p$-xylene in comparison with $o$-xylene and $m$-xylene to $p$-xylene was 250 at $473 \mathrm{~K}$ (Sakai et al., 2001).

Without considering the thermal compatibility between the membrane and the support, Xomeritakis et al. (2001) conducted a comparative study that produced the same type of zeolite membrane, but with different pore direction. They used MFI-type membranes, synthesized by secondary growth, supported in $\alpha-\mathrm{Al}_{2} \mathrm{O}_{3}$ discs. The researchers produced two types of membranes, which differed on the orientation of the zeolite pores. Initially, the behavior of xylene permeation was studied in the presence of hexane in c-oriented MFI membranes with thickness ranging between 12 and $18 \mu \mathrm{m}$. At this stage, they observed a decrease in the flow of isomers' permeation. However, there was an increase in the separation factor from $\sim 5$ to 37 . Comparing the membrane permeation results of the two membranes, these scientists listed three different types of paths that interfered in the permeation of substances in the membrane. The first path was observed with a zeolite featuring 5.5-Å pores; the second had nonzeolite micropore spaces between adjacent zeolite crystals, with the size of $10 \AA$; in the third path, mesopores with sizes larger than $20 \AA$ were observed that were considered to be defective.

The evaluation of these membranes was performed by permeation experiments that involved only one component and binary and ternary mixtures, with the temperature ranging from 22 to $300{ }^{\circ} \mathrm{C}$, and partial feed pressures of up to $\sim 1 \mathrm{kPa}$. The c-oriented MFI-type membranes with 12 to $18 \mu \mathrm{m}$ thickness showed an increase in the $o$-xylene flow (in the binary mixtures study). The authors of this research attributed this behavior to the pronounced presence of intercrystal pores among adjacent crystals of the zeolite, which can increase $o$-xylene's permeation rates, resulting in a low separation factor between $p$-xylene and $o$-xylene. After addition of hexane to the feed, there was a significant improvement in the separation performance, probably because of preferential adsorption on the zeolite pores and/or non-zeolite pores, and a substantial reduction in the $o$-xylene's permeation flow. The MFI-type membranes were thinner $(2 \mu \mathrm{m})$ and (hOh)oriented, showing a high degree of intergrowth among zeolite crystals and high separation factors (30-290) among the xylene isomers. This result is associated to the absence of defective non-zeolite micropores due to specific conditions during membrane's formation.

In 2002, Jobic et al. evaluated the diffusivity of xylene isomers in BaX zeolite using a novel technique. The scientists performed experiments using ( $p$-xylene $+m$-xylene) binary mixtures, comparing their diffusivities, mobilities and selectivities. The zeolite was synthesized by ionic exchange using the neutron spin echo technique. On the BaX zeolite, the xylene molecule diffusivities 
were in the $10^{-12}$ to $10^{-13} \mathrm{~m}^{2} \cdot \mathrm{s}^{-1}$ range. This implied that the micropore diffusion could limit this diffusivity rates. Furthermore, the difference between xylene molecules was much greater in $\mathrm{NaX}$ than in BaX. The para isomer spread about three times faster in BaX than the meta isomer, which was only 10-25\% faster in NaX (Jobic et al., 2001).

Tarditi et al. (2006) prepared a MFI-type membrane supported on a stainless steel tube (ZSM-5/SS), and evaluated its efficiency in separating xylene isomers. During the development of the experiment, the scientists were concerned with the possibility of incompatibility between the zeolite and the stainless steel because of thermal expansion. However, the results proved that the membrane produced had high quality, in that it was free of cracks or preferential paths. Also, permeation experiments with a single component and with ternary mixtures showed that the membrane under investigation was selective for $p$ xylene, and even when operating at $400{ }^{\circ} \mathrm{C}$ it had good separation factors $\left(\mathrm{Fs}_{p / 0-x y l}=4.4\right.$ and $\mathrm{Fs}_{p / m-x y l}=$ 4.3). In light of this study, the researchers were able to prove that the ZSM-5 membrane on a stainless steel support did not reveal cracks, even when exposed to 1000 hours of operation under temperatures that ranged from 150 to $400{ }^{\circ} \mathrm{C}$. These results could be attributed to the roughness and the porosity of the support's surface, which gave the interface a certain amount of flexibility. It was also proven that the diffusion of $p$-xylene was much more intense than the one attained by the other isomers, when individually analyzed. In the mixture (formed by the three xylene isomers), the molecule size should not be the only factor to be considered, since there is also a difference in interactive adsorption that affects the separation factors in isomers. In 2008, Tarditi et al. examined the influence of the cation present in the zeolite in the separation of xylene isomers, investigating the permeation behavior. Contrasting this work against the one developed previously by the same authors, the permeation flow presented the same behavior when exposed to temperatures that ranged between 150 and $400{ }^{\circ} \mathrm{C}$. The permeation flow increased with the increase in temperature. This increase in permeation flow was even more pronounced for ortho and meta isomers. All the ZSM-5/SS membranes that were charged with $\mathrm{Na}^{+}$, $\mathrm{Cs}^{+}, \mathrm{Sr}^{2+}$ and $\mathrm{Ba}^{2+}$ presented selectivity to $p$-xylene (Tarditi et al., 2006; Tarditi and Lombardo, 2008).
With the recent advances in material engineering reported for the last ten years, research using MOFs in the separation of xylene isomers has become available. The MIL-53 (Alaerts et al., 2008; Finsy et al., 2009; Moreira et al., 2011a) and the MIL-47 (Castillo et al., 2009; Finsy et al., 2009) MOFs are currently being tested in behavior studies involving $C_{8}$ hydrocarbon mixtures together with their use in the fracturing of these mixtures. Similar materials have also been used in other studies (Deng et al., 2010; Gu et al., 2010; Nicolau et al., 2009; Wu et al., 2009). These experiments produced the adsorption isotherms and breakthrough curves that are required to provide information on the selectivity between the isomers.

\section{CONCLUSIONS}

This review showed the great potential of microporous materials in adsorption processes and their large variety of structures. The use of zeolites in the separation of xylene isomers inspired a series of academic researches, but the number of satisfactory results is still limited. Among the successful experiences to separate xylene isomers, the PAREX process is highlighted, which is used in the commercial separation of $p$-xylene isomers, followed by another process (ISOMAR) which transforms the remaining isomers in $p$-xylene.

Despite the number of articles that address the separation of isomers, the potential of this research topic is yet to be fully explored. The search for novel ways to improve the processes is motivated by the material's added economic value. The trend of developing new materials, such as MOFs, and the challenge of improving the efficiency in the separation of pure isomers leave the horizon open for new research opportunities.

\section{ACKNOWLEDGEMENTS}

The authors of this research would like to thank PRH-ANP 14 and Petrobras for financial support. 


\section{REFERENCES}

Adams, G. F. Process for the production of para-xylene. US n.3.624.172, Nov.30, 1971.

Alaerts, L.; Maes, M.; Giebeler, L.; Jacobs, P. A.; Martens, J. A.; Denayer, J. F. M.; Kirschhock, C. E. A.; De Vos, D. E. Selective adsorption and separation of ortho-substituted alkylaromatics with the microporous aluminum terephthalate MIL-53. Journal of the American Chemical Society, v.130, p.14170-14178, 2008.

http://dx.doi.org/10.1021/ja802761z

Amir, E. M. Production of $\mathbf{m}$-xylene. US n.3.539.650, Nov. 10, 1970.

Antos, G. J.; Flint, N. J. Separation of orthoxylene. US n.4.529.828, Jul. 161985.

Baddour, R. F.; Michaels, A. S. Permeable membrane and method of making same for use in a paraxylene separation. US n.3.299.157, Jan. 17, 1967.

Baertsch, C. D.; Funke, H. H.; Falconer, J. L.; Noble, R. D. Permeation of aromatic hydrocarbon vapors through silicalite-zeolite membranes. Journal of Physical Chemistry, v.100, p.7676-7679, 1996. http://dx.doi.org/10.1021/ip960226h

Berg, L. Separation of $\mathbf{m}$-xylene from o-xylene or p-xylene by azeotropic distillation. US n.5.039.380, Aug. 13, 1991.

Berg, L. Separation of $\mathbf{p}$-xylene from $\mathbf{m}$-xylene by extractive distillation. US n.5.091.059, Feb. 25, 1992.

Bonilla, G.; Tsapatsis, M.; Vlachos, D. G.; Xomeritakis, G. Fluorescence confocal optical microscopy imaging of the grain boundary structure of zeolite MFI membranes made by secondary (seeded) growth. Journal of Membrane Science, v.182, p.103-109, 2001.

http://dx.doi.org/10.1016/S0376-7388(00)00549-4

Bown, D. E. Recovery of durene by forming a co-crystallized solid with symmetrical tetrachloroethane. US n.2.815.392, Dec. 3, 1957a.
Bown, D. E.; Milligan, W. O. Process for recovering polymethyl aromatic compounds containing para-methyl groupings by fractional crystallization in the presence of chloral. US n.2.801.272, July 30, 1957b.

Breck, D. W. Zeolite Molecular Sieve. New York: John Wiley \& Sons, 1974.

Brzostowska, E.; Milewski, M.; Berak, J. M. Application of Zeolite ZSM-5 for Separation of Xylene Mixture and Ethylbenzene. Przemysl Chemiczny, v.60, p.95-96, 1981.

Carrà, S.; Santacesaria, E. ; Morbidelli, M. ; Storti, G.; Gelosa, D. Separation of xylenes on $Y$ zeolites. 3. Pulse curves and their interpretation. Industrial and Engineering Chemistry Process Design and Development, v.21, p.451-457, 1982. http://dx.doi.org/10.1021/i200018a018

Castillo, J. M.; Vlugt, T. J. H.; Calero, S. Molecular simulation study on the separation of xylene isomers in MIL-47 metal - Organic frameworks. Journal of Physical Chemistry C, v.113, p.2086920874, 2009.

http://dx.doi.org/10.1021/jp908247w

Daramola, M. O.; Burger, A. J.; Pera-Titus, M.; Giroir-Fendler, A.; Lorenzen, L.; Dalmon, J. A. Xylene vapor mixture separation in nanocomposite MFI-alumina tubular membranes: Influence of operating variables. Separation Science and Technology, v.45, p.21-27, 2010.

http://dx.doi.org/10.1080/01496390903402141

Denayer, J.; Finsy, V.; De Vos, D.; Baron, G. V. (2008). Breathing effects in the adsorption and separation of xylene isomers on the metal organic framework MIL-53. AIChE 100 - 2008 AIChE Annual Meeting, Conference Proceedings.

Deng, Z.; Nicolas, C. H.; Guo, Y.; Giroir-Fendler, A.; Pera-Titus, M. Synthesis and characterization of nanocomposite B-MFI-alumina hollow fibre membranes and application to xylene isomer separation. Microporous and Mesoporous Materials, v.133, p.18-26, 2010. http://dx.doi.org/10.1016/j.micromeso.2010.04.006

Eberly, P. E. and Arey, W. F. Separation of paraxylene. US n.3.126.425, Mar. 24, 1964. 
Faulkner, W. D. Separation of xylenes. US n.3.868.429, Feb. 25, 1975.

Finsy, V.; Kirschhock, C. E. A.; Vedts, G.; Maes, M.; Alaerts, L.; De Vos, D. E.; Baron, G. V.; Denayer, J. F. M. Framework breathing in the vapour-phase adsorption and separation of xylene isomers with the metal-organic framework MIL-53. Chemistry A European Journal, v.15, p.7724-7731, 2009. http://dx.doi.org/10.1002/chem.200802672

Finsy, V.; Verelst, H.; Alaerts, L.; De Vos, D.; Jacobs, P. A.; Baron, G. V.; Denayer, J. F. M. Porefilling-dependent selectivity effects in the vaporphase separation of xylene isomers on the metalorganic framework MIL-47. Journal of the American Chemical Society, v.130, p.7110-7118, 2008. http://dx.doi.org/10.1021/ja800686c

Flanigen, E. M. Molecular sieve zeolite technology - The first twenty-five years. Pure \& Appl.Chem., 2191 - 2211, 1980. http://dx.doi.org/10.1351/pac198052092191

Fleck, R. N.; Wight, C. G. Diffusional separation of aromatic compounds. US n.2.983.767, May 9, 1961.

Furlan, L. T.; Chaves, B. C.; Santana, C. C. Separation of liquid mixtures of $p$-xylene and oxylene in $X$ zeolites: The role of water content on the adsorbent selectivity. Industrial \& Engineering Chemistry Research, v.31, p.1780-1784, 1992.

http://dx.doi.org/10.1021/ie00007a024

Greene, R. B. Recovery of ortho-xylene by chemical treatment and distillation. US n.2.504.830, Apr. 18, 1950.

Gu, Z. Y.; Jiang, D. Q.; Wang, H. F.; Cui, X. Y.; Yan, $X$. P. Adsorption and separation of xylene isomers and ethylbenzene on two $\mathrm{Zn}$-terephthalate metalorganic frameworks. Journal of Physical Chemistry C, v.114, p.311-316, 2010. http://dx.doi.org/10.1021/ip9063017

Guo, G. Q.; Chen, H.; Long, Y. C. Separation of pxylene from C8 aromatics on binder-free hydrophobic adsorbent of MFI zeolite. I. Studies on static equilibrium. Microporous and Mesoporous Materials, v.39, p.149-161, 2000.

http://dx.doi.org/10.1016/S1387-1811(00)00191-8
Health Canada. Toluene, ethylbenzene and the xylene. Available at: http://dsppsd.pwgsc.gc.ca/Collection/H48-10-1-781988E.pdf. Accessed on: 10 November 2011.

Hoff, M. C.; Burney, D. E. Separation of xylene isomers. US n.2.848.517, Aug. 19, 1958.

Jansen, K. C.; Coker, E. N. Zeolitic membranes. Current Opinion in Solid State and Materials Science, v.1, p.65-68, 1996.

http://dx.doi.org/10.1016/S1359-0286(96)80012-X

Jin, J. H.; Suh, J. K.; Hong, J. S.; Kim, B. S.; Lee, C. $\mathrm{H}$. Study on characteristics and preparation of bindeiless $\mathrm{BaX}$ granules for separation of $\mathrm{p}$-xylene. Journal of the Korean Industrial and Engineering Chemistry, v.20, p.80-86, 2009.

Jobic, H.; Bée, M.; Méthivier, A.; Combet, J. Influence of the cation compositon on the dynamics of xylenes in X-type zeolites. Microporous and Mesoporous Materials, v.42, p.135-155, 2001. http://dx.doi.org/10.1016/S1387$\underline{1811(00) 00335-8}$

Lake, G. R.; McDowell, J. M. Azeotropic separation of xylene isomers. US n.2.456.561, Dec. 14, 1948.

Matsufuji, T.; Nishiyama, N.; Matsukata, M.; Ueyama, K. Separation of butane and xylene isomers with MFI-type zeolitic membrane synthesized by a vapor-phase transport method. Journal of Membrane Science, v.178, p.25-34, 2000. http://dx.doi.org/10.1016/50376-7388(00)00462-2

McCaulay, D. A. Separation of xylene isomers. US n.3.309.414, Mar. 14, 1967.

Methivier, A. Influence of Oxygenated Contaminants on the Separation of C8 Aromatics by Adsorption on Faujasite Zeolites. Industrial and Engineering Chemistry Research, v.37, p.604-608, 1998. http://dx.doi.org/10.1021/ie9606294

Meyers, R. A. Handbook of Petroleum Refining Processes. Los Angeles: McGraw-Hill Professional, 2003. 900p.

Mikitenko, P.; MacPherson, S. R. Process for separating paraxylene comprising at least two crystallization stages at high temperature. US n.6.147.272, Nov. 14, 2000. 
Milewski, M.; Berak, J. M. Use of Modified NaY Zeolite in the Separation of Meta- and ParaIsomers of Xylene. Przem Chem, v.54, p.698-699, 1975.

Morbidelli, M.; Santacesaria, E.; Storti, G.; Carrà, S. Separation of xylenes on $Y$ zeolites in the vapor phase. 2. Breakthrough and pulse curves and their interpretation. Industrial and Engineering Chemistry Process Design and Development, v.24, p.83-88, 1985. http://dx.doi.org/10.1021/i200028a015

Morbidelli, M.; Storti, G.; Carrà, S. Comparison of adsorption separation processes in the liquid and vapor phase. Application to the xylene isomer mixture. Industrial and Engineering Chemistry Fundamentals, v.25, p.89-95, 1986.

http://dx.doi.org/10.1021/i100021a013

Moreira, M. A.; Santos, J. C.; Ferreira, A. F. P.; Loureiro, J. M.; Rodrigues, A. E. Influence of the eluent in the MIL-53(Al) selectivity for xylene isomers separation. Industrial and Engineering Chemistry Research, v.50, p.7688-7695, 2011a. http://dx.doi.org/10.1021/ie200206n

Moreira, M. A.; Santos, J. C.; Ferreira, A. F. P.; Müller, U.; Trukhan, N.; Loureiro, J. M.; Rodrigues, A. E. Selective liquid phase adsorption and separation of ortho-xylene with the microporous MIL-53(Al). Separation Science and Technology, v.46, p.1995-2003, 2011b.

http://dx.doi.org/10.1080/01496395.2011.594481

Nair, S.; Lai, Z.; Nikolakis, V.; Xomeritakis, G.; Bonilla, G.; Tsapatsis, M. Separation of close-boiling hydrocarbon mixtures by MFI and FAU membranes made by secondary growth. Microporous and Mesoporous Materials, v.48, p.219-228, 2001. http://dx.doi.org/10.1016/S1387-1811(01)00356-0

Namba, S.; Kanai, Y.; Shoji, H.; Yashima, T. Separation of $p$-isomers from disubstituted benzenes by means of shape-selective adsorption on mordenite and ZSM-5 zeolites. Zeolites, v.4, p.77-80, 1984.

http://dx.doi.org/10.1016/0144-2449(84)90078-2

Nicolau, M. P. M.; Bárcia, P. S.; Gallegos, J. M.; Silva, J. A. C.; Rodrigues, A. E.; Chen, B. Single- and multicomponent vapor-phase adsorption of xylene isomers and ethylbenzene in a microporous metalorganic framework. Journal of Physical Chemistry C, v.113, p.13173-13179, 2009.

http://dx.doi.org/10.1021/ip9006747
Nixon, A. C.; Deal, C. H. Process of contacting hydrocarbons mixtures with antimony trichloride. US n.2.638.441, May 12, 1953.

Nixon, A. C.; Deal, C. H.; Evans, R. J. Separation of $\mathrm{C}_{8} \mathrm{H}_{10}$ aromatic hydrocarbons by extractive distillation. US n.2.532.031, Nov. 28, 1950.

O'Brien-Abraham, J.; Duke, M.; Lin, Y. S. Xylene Separation Performance of Composition-Gradient MFI Zeolite Membranes. Membrane Science and Technology, v.14, p.195-212, 2011.

O'Brien-Abraham, J.; Kanezashi, M.; Lin, Y. S. Effects of adsorption-induced microstructural changes on separation of xylene isomers through MFI-type zeolite membranes. Journal of Membrane Science, v.320, p.505-513, 2008. http://dx.doi.org/10.1016/j.memsci.2008.04.023

Pearce, D. Xylene separation process. US n.3.939.221, Feb. 17, 1976.

Rasouli, M.; Yaghobi, N.; Chitsazan, S.; Sayyar, $M$. H. Influence of monovalent cations ionexchange on zeolite ZSM-5 in separation of paraxylene from xylene mixture. Microporous and Mesoporous Materials, v.150, p.47-54, 2011.

Rosback, D. H. Adsorptive separation of aromatic isomers. US n.4.283.587, Aug. 11, 1981.

Rouquerol, J.; Avnir, D.; Fairbridge, C. W. Recomendations for the chracterization of the porous solids. Pure Appl.Chem., 1739, 1994. http://dx.doi.org/10.1351/pac199466081739

Sakai, H.; Tomita, T.; Takahashi, T. p-Xylene separation with MFI-type zeolite membrane. Separation and Purification Technology, v.25, p.297-306, 2001.

http://dx.doi.org/10.1016/S1383-5866(01)00056-9

Santacesaria, E. Metodi di separazione degli xilene isomeri. La Chimica e L'Industria, v.62, p.317-322, 1980. (in Italian)

Santacesaria, E.; Gelosa, D.; Danise, P.; Carrà, S. Separation of xylenes on $Y$ zeolites in the vapor phase. 1. Determination of the adsorption equilibrium parameters and of the kinetic regime. Industrial and Engineering Chemistry Process Design and Development, v.24, p.78-83, 1985. http://dx.doi.org/10.1021/i200028a014 
Santacesaria, E.; Morbidelli, M.; Danise, P.; Mercenari, M.; Carrà, S. Separation of xylenes on Y zeolites. 1. Determination of the adsorption equilibrium parameters, selectivities, and mass transfer coefficients through finite bath experiments. Industrial and Engineering Chemistry Process Design and Development, v.21, p.440-445, 1982a. http://dx.doi.org/10.1021/i200018a016

Santacesaria, E.; Morbidelli, M.; Servida, A.; Storti, G.; Carrà, S. Separation of xylenes on $Y$ zeolites. 2. Breakthrough curves and their interpretation. Industrial and Engineering Chemistry Process Design and Development, v.21, p.446-451, 1982b.

http://dx.doi.org/10.1021/i200018a017

Sayari, A. Catalysis by Crystalline Mesoporous Molecular Sieves. Chemistry of Materials, v.8, p.1840-1852, 1996.

http://dx.doi.org/10.1021/cm950585+

Schaeffer, W. D. Separation of aromatic hydrocarbon mixtures. US n.3.277.201, Oct. 4, 1966.

Schaeffer, W. D.; Wordie, J. D. Separation of C-8 aromatic hydrocarbon isomers using Werner complex. US n.2.951.104, Aug. 30, 1960.

Shaeffer, W. D.; Wordle, J. D. Separation of aromatic compounds by clathrate formation with a Werner complex. US n.2.798.103, July 2, 1957.

Smolin, W. Process for separation of aromatic hydrocarbons. US n.3.311.670, Mar. 28, 1967.

Smolin, W. Separation of para-xylene. US n.4.351.981, Sep. 28, 1982.

Stenmark, D. G. Separation of aromatics. US n.3.707.577, Dec. 26, 1972.

Storti, G.; Mazzotti, M.; Tadeu Furlan, L.; Morbidelli, M.; Carra, S. Performance of a six-port simulated moving-bed pilot plant for vapor-phase adsorption separations. Separation Science and Technology, v.27, p.1889-1916, 1992.

http://dx.doi.org/10.1080/01496399208019456

Storti, G.; Santacesaria, E.; Morbidelli, M.; Carrà, S. Separation of xylenes on $Y$ zeolites in the vapor phase. 3. Choice of the suitable desorbent. Industrial and Engineering Chemistry Process Design and Development, v.24, p.89-92, 1985. http://dx.doi.org/10.1021/i200028a016
Swalowski, T. H.; Rai, C. Method for separating meta-para xylene mixtures. US n.3.414.630, Dec. 3, 1968.

Talbot, J. L. Separation of xylene isomers. US n.2.738.372, Mar. 13, 1956.

Tan, C.-S. Process for separation of ethylbenzene or ethylbenzene/p-xylene from a xylene isomers mixture. US n.5.227.570, Jul. 13, 1993.

Tarditi, A. M.; Horowitz, G. I.; Lombardo, E. A. A durable ZSM-5/SS composite tubular membrane for the selective separation of $p$-xylene from its isomers. Journal of Membrane Science, v.281, p.692-699, 2006.

http://dx.doi.org/10.1016/i.memsci.2006.04.041

Tarditi, A. M.; Lombardo, E. A. Influence of exchanged cations ( $\mathrm{Na}+, \mathrm{Cs}+, \mathrm{Sr} 2+$ and $\mathrm{Ba} 2+$ ) on xylene permeation through ZSM-5/SS tubular membranes. Separation and Purification Technology, v.61, p.136-147, 2008. http://dx.doi.org/10.1016/i.seppur.2007.10.008

Tarditi, A. M.; Lombardo, E. A.; Avila, A. M. Xylene permeation transport through composite Ba-ZSM-5/SS tubular membranes: Modeling the steady-state permeation. Industrial and Engineering Chemistry Research, v.47, p.23772385, 2008. http://dx.doi.org/10.1021/ie071296I

Walker, D. G.; Long, R. B. Process for the separation of aromatic isomers. US n.3.565.965, Feb. 23, 1971.

Wegner, K.; Dong, J.; Lin, Y. S. Polycrystalline MFI zeolite membranes: Xylene pervaporation and its implication on membrane microstructure. Journal of Membrane Science, v.158, p.17-27, 1999. http://dx.doi.org/10.1016/\$0376-7388(98)00339-1

Wu, Z.; Yang, Y.; Tu, B.; Webley, P. A.; Zhao, D. Adsorption of xylene isomers on ordered hexagonal mesoporous FDU-15 polymer and carbon materials. Adsorption, v.15, p.123-132, 2009. http://dx.doi.org/10.1007/s10450-009-9159-8

Xomeritakis, G.; Lai, Z.; Tsapatsis, M. Separation of xylene isomer vapors with oriented $\mathrm{MFI}$ membranes made by seeded growth. Industrial and Engineering Chemistry Research, v.40, p.544552, 2001. http://dx.doi.org/10.1021/ie000613k 
Xomeritakis, G.; Tsapatsis, M. Permeation of aromatic isomer vapors through oriented MFI-type membranes made by secondary growth. Chemistry of Materials, v.11, p.875-878, 1999. http://dx.doi.org/10.1021/cm9811343

Yan, T. Y. Separation of $p$-xylene and ethylbenzene from C8 aromatics using mediumpore zeolites. Industrial and Engineering Chemistry Research, v.28, p.572-576, 1989. http://dx.doi.org/10.1021/ie00089a012
Zhao, T.; Li, B.; Wang, Z.; Li, S.; Wang, J.; Yu, Z. Distribution of cation in BaX zeolite and mechanism of adsorption and separation for paraxylene. Chinese Journal of Catalysis, v.26, p.655-659, 2005.

Zinnen, H. A. and McGonegal, C. P. Process for separating meta-xylene. US n.6.137.024, Oct. 24, 2000. 